\title{
Blood lead and erythrocyte $\delta$-aminolevulinic acid dehydratase levels in Manchester taxi drivers
}

\author{
M. L. H. FLINDT1, E. KING ${ }^{2}$, and D. B. WALSH ${ }^{3}$
}

Department of Occupational Health, University of Manchester ${ }^{1}$, National Occupational Hygiene Service Limited, Manchester ${ }^{2}$, and Department of Clinical Pathology, Manchester Royal Infirmary

\begin{abstract}
Flindt, M. L. H., King, E., and Walsh, D. B. (1976). British Journal of Industrial Medicine, 33, 79-84. Blood lead and erythrocyte $\delta$-aminolevulinic acid dehydratase levels in Manchester taxi drivers. Among 40 Manchester taxi drivers the mean blood lead was $1 \cdot 10 \mu \mathrm{mol} / 1(22.8 \mu \mathrm{g}$ per $100 \mathrm{ml}$ ). The mean erythrocyte $\delta$-aminolevulinic acid dehydratase (ALAD) activity among 34 of them was $30 \cdot 1$ units. No significant association was found between the blood lead levels and erythrocyte ALAD activity in these 34 men. No significant association was found between either blood lead levels or erythrocyte ALAD activity and duration of service or weekly mileage as a taxi driver or with drinking or smoking habits, or age. The mean blood lead of those with homes in the north east quadrant of the city was higher than of those living elsewhere but the difference was not statistically significant. Although there was no correlation between blood lead levels and the source of domestic water, the mean blood lead of those with lead domestic plumbing was appreciably higher than the level of those with copper plumbing. There was no indication that, by virtue of their occupation, the taxi drivers were liable to greater lead absorption than their fellow-citizens.
\end{abstract}

The current interest in the possible contribution of lead from motor-car exhaust to atmospheric pollution, with potential harmful effects on health, led Jones, Commins, and Cernik (1972) to measure the level of lead in the blood of 50 London taxi drivers. They also estimated carboxyhaemoglobin levels, using these as an index of exhaust exposure. They found that, whereas the day-shift men had higher carboxyhaemoglobin levels than those on the night-shift, there was no significant difference between the blood lead levels in the two groups, and they concluded that little of the lead in the blood of their subjects derived from inhalation while driving in London streets.

While accepting these authors' reasoning in respect of the relative exhaust exposure of the two

'Present address: Department of Clinical Chemistry, Ninewells Hospital and Medical School, Dundee. groups, we noted that they found a mean blood lead level of $1.39 \mu \mathrm{mol} / 1(28.7 \mu \mathrm{g}$ per $100 \mathrm{ml})$ in the drivers. The authors stated that their values were not dissimilar to those found in other town dwellers but, in the references they cited, mean blood levels of the same order were found only among groups in whom an increased occupational or environmental exposure was postulated (Ludwig et al., 1965), or in cases in which there was evidence of raised dietary levels of lead (Zurlo, Griffini, and Vigliani, 1970). Thomas et al. (1967) found a mean blood lead level of $1 \cdot 16$ $\mu \mathrm{mol} / 1(22.7 \mu \mathrm{g}$ per $100 \mathrm{~g})$ for males living near freeways, levels not substantially higher than those for other urban Los Angeles populations. Other papers from outside the United Kingdom (Lehnert, 1967; Mann, Senchea, and Roventa, 1969; Arroyo and Soldevilla, 1970) have given mean blood lead levels of between 0.77 and $1.06 \mu \mathrm{mol} / 1$ (16 and $22 \mu \mathrm{g}$ per 100 $\mathrm{ml}$ ), and among urban samples submitted from 16 
countries for a central laboratory study (Goldwater and Hoover, 1967), only those from Finland with a mean blood lead level of $1.35 \mu \mathrm{mol} / 1 \mathrm{l}(28 \mu \mathrm{g}$ per 100 $\mathrm{ml})$, gave mean values higher than $1.11 \mu \mathrm{mol} / 1(23 \mu \mathrm{g}$ per $100 \mathrm{ml}$ ). The samples from England submitted for this survey gave a mean value of $1.11 \mu \mathrm{mol} / \mathrm{l}$ $(23 \mu \mathrm{g}$ per $100 \mathrm{ml})$.

We therefore decided to measure blood lead in a group of central Manchester taxi drivers to see how our findings compared with those of Jones et al., 1972. We also arranged to assay the erythrocyte $\delta$-aminolevulinic acid dehydratase activity of the samples. It has been stated that inhibition of erythrocyte ALAD activity is the most sensitive biochemical manifestation of lead absorption so far known (Hernberg et al., 1972), and that there is an inverse correlation between blood lead levels and erythrocyte ALAD activity, even at blood lead levels found in non-industrially exposed city dwellers (Hernberg and Nikkanen, 1970; Hernberg et al., 1970).

\section{Materials and methods}

Blood samples were obtained from male taxi driver volunteers while they were refuelling at a central Manchester depot. Not more than six men were interviewed and bled on each occasion, so as to ensure that less than two hours would elapse between collection of any of the specimens and the start of the ALAD estimations. The blood was taken into lead-free heparinized syringes and, after the portion for ALAD estimations had been removed, the samples were stored in a refrigerator until they were all available for lead estimation. Blood lead was measured in 40 samples and ALAD activity in 34 of them.

The men's ages, home addresses, and drinking and smoking habits were recorded, as was the length of time they had spent as taxi drivers, their estimated weekly mileages, and whether they were on day or night shift.

Blood lead estimations were carried out using the single tube monocolor dithizone technique described by Hoschek and Schittke (1973). In this technique about $3 \mathrm{~g}$ blood (weighed) is wet-ashed in a boiling tube with a mixture of nitric, perchloric, and sulphuric acids to the sulphuric acid refluxing stage. After adding $10 \mathrm{ml}$ water, the sample is made up to about $\mathrm{pH} 9.5$ with ammonia ammonium citrate, and a cyanide complexing mixture is added. It is then extracted with a solution of dithizone in chloroform, the aqueous phase being discarded. The excess dithizone is then removed by quadruple extraction with ammonia/cyanide wash solution and the absorption of the final pink dithizonate read at $515 \mathrm{~nm}$. The whole operation, except the final absorption reading, takes place in the same boiling tube. The laboratory which carried out the investigations is No. 52 in the National Quality Control Scheme organized by Professor T. P. Whitehead of the Wolfson Research Laboratories, Department of Clinical Chemistry, Queen Elizabeth Medical Centre, Edgbaston, Birmingham. The scheme covers a number of analyses, one of them being 'lead in blood'. At about monthly intervals samples from a single source are sent to the participant laboratories, which are coded by number. The analytical result is returned to the Queen Elizabeth Medical Centre and each trial is reported back to the laboratories in terms of the results from each laboratory with a simple statistical analysis of the data.

Erythrocyte ALAD activity was measured by a micromodification of the method of Weissberg, Lipschutz, and Oski (1971), in which reduced glutathione was incorporated into the substrate. This modification was introduced to counteract the rapid fall in activity experienced after sampling. The optimal concentration was in agreement with that quoted by Gibson, Neuberger, and Scott (1955). By this technique it was found that there was no difference in measured levels of ALAD activity from the time of sampling up to the chosen limit of two hours.

\section{Results and discussion}

The results are presented in Table 1 . The ages of the 40 men ranged from 25 to 64 years with a mean of 40 (SD 10.8). Their lengths of service as taxi drivers ranged from three months to 36 years with a mean of 11 years (SD 8). Estimated mileages of 38 of the men ranged from 400 to 1000 miles a week with a mean of 664 miles (SD 153). Altogether 25 of the men were on day work, twelve did alternating day and night work, and three were doing night shifts only.

Blood lead levels among $\mathbf{4 0}$ drivers varied between $0.58 \mu \mathrm{mol} / \mathrm{l}$ and $1.98 \mu \mathrm{mol} / \mathrm{l}(12$ and $41 \mu \mathrm{g}$ per 100 $\mathrm{ml})$ with a mean of $1.10 \mu \mathrm{mol} / 1, \mathrm{SD} 0.37(22.8 \mu \mathrm{g}$ per $100 \mathrm{ml}$, SD 7.6). Erythrocyte ALAD activities among 34 drivers varied between 14.7 and 47.0 units $(\mu / \mathrm{mol}$ of porphobilinogen $/ \mathrm{min}$ per $\mathrm{ml}$ of red cells), with a mean of $30 \cdot 1$ (SD 7.9).

No statistically significant association was observed between the blood lead levels and the ALAD activity in these 34 drivers $(r=-0.07$ see Figure). There was no apparent association between either blood lead or ALAD levels and the nature or length of service or weekly mileage as a taxi driver, drinking or smoking habits, or age.

When the blood leads of the taxi drivers are considered in relation to the positions of their homes on the map, the average of the blood leads appears to be somewhat higher in the north east quadrant of the city (see Table 2). This is the quadrant which might be expected to receive the bulk of the airborne pollution from the city as the prevailing wind is from the south west. The differences in the mean blood leads between the quadrants is, however, not sufficiently large to be statistically significant (P $>0.10$ in a Student's $t$ test of north east and south west quadrants) and might be due to other factors.

Particulars were obtained concerning the water supply to the homes of 34 of the men. These homes were supplied from six different water sources but there was no apparent correlation between the blood lead levels of the men and the source of their domestic water, nor whether the service pipe from 
TABLE 1

FINDINGS IN TAXI DRIVERS

\begin{tabular}{|c|c|c|c|c|c|c|c|c|}
\hline $\begin{array}{c}\text { Series } \\
(\text { no. })\end{array}$ & $\begin{array}{c}\text { Age } \\
\text { (years) }\end{array}$ & $\begin{array}{l}\text { Smoking } \\
\text { (see key) }\end{array}$ & $\begin{array}{l}\text { Drinking } \\
\text { (see key) }\end{array}$ & $\begin{array}{l}\text { Years of } \\
\text { driving }\end{array}$ & $\begin{array}{l}\text { Weekly } \\
\text { mileage }\end{array}$ & Shift & $\begin{array}{c}\text { Blood-lead } \\
\mu \text { molll } \\
(\mu \mathrm{g} \mathrm{per} \\
100 \mathrm{ml})\end{array}$ & $\begin{array}{l}\text { ALAD } \\
\text { units }\end{array}$ \\
\hline $\begin{array}{r}1 \\
2 \\
3 \\
4 \\
5 \\
6 \\
7 \\
8 \\
9 \\
10 \\
11 \\
12 \\
13 \\
14 \\
15 \\
16 \\
17 \\
18 \\
19 \\
20 \\
21 \\
22 \\
23 \\
24 \\
25 \\
26 \\
27 \\
28 \\
29 \\
30 \\
31 \\
32 \\
33 \\
34 \\
35 \\
36 \\
37 \\
38 \\
39 \\
40\end{array}$ & $\begin{array}{l}25 \\
50 \\
34 \\
63 \\
37 \\
43 \\
35 \\
36 \\
31 \\
26 \\
34 \\
30 \\
64 \\
50 \\
25 \\
43 \\
28 \\
48 \\
43 \\
37 \\
29 \\
39 \\
55 \\
37 \\
25 \\
38 \\
53 \\
42 \\
45 \\
63 \\
34 \\
57 \\
27 \\
32 \\
40 \\
45 \\
40 \\
45 \\
29 \\
34\end{array}$ & $\begin{array}{l}0 \\
0 \\
1 \\
4 \\
3 \\
0 \\
4 \\
1 \\
4 \\
0 \\
3 \\
0 \\
0 \\
0 \\
3 \\
4 \\
4 \\
4 \\
4 \\
0 \\
0 \\
3 \\
4 \\
1 \\
1 \\
0 \\
4 \\
3 \\
4 \\
3 \\
3 \\
1 \\
2 \\
3 \\
0 \\
0 \\
3 \\
2 \\
3 \\
2\end{array}$ & $\begin{array}{l}1 \\
3 \\
0 \\
1 \\
1 \\
1 \\
2 \\
1 \\
2 \\
2 \\
1 \\
2 \\
2 \\
0 \\
1 \\
3 \\
2 \\
4 \\
0 \\
0 \\
0 \\
2 \\
4 \\
2 \\
3 \\
2 \\
1 \\
1 \\
0 \\
0 \\
2 \\
0 \\
4 \\
4 \\
2 \\
3 \\
0 \\
3 \\
2 \\
0\end{array}$ & $\begin{array}{r}3 \\
8 \\
7 \\
20 \\
8 \\
9 \\
9 \\
6 \\
8 \\
1 \\
10 \\
8 \\
12 \\
10 \\
2 \\
20 \\
5 \\
36 \\
15 \\
15 \\
7 \\
9 \\
20 \\
10 \\
1 \\
12 \\
16 \\
21 \\
14 \\
30 \\
8 \\
25 \\
4 \\
12 \\
2 \\
10 \\
17 \\
10 \\
1 \\
10\end{array}$ & $\begin{array}{r}600 \\
500 \\
900 \\
450 \\
700 \\
- \\
\overline{6} \\
600 \\
1000 \\
800 \\
650 \\
600 \\
600 \\
600 \\
600 \\
450 \\
600 \\
600 \\
800 \\
400 \\
700 \\
700 \\
600 \\
500 \\
750 \\
700 \\
550 \\
900 \\
1000 \\
600 \\
700 \\
500 \\
650 \\
1000 \\
850 \\
600 \\
600 \\
500 \\
700 \\
700 \\
\end{array}$ & 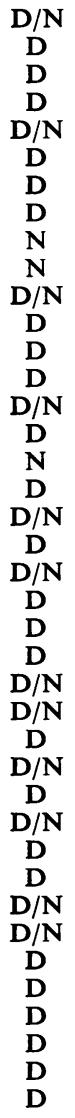 & $\begin{array}{l}0.68(14) \\
0.72(15) \\
0.97(20) \\
0.68(14) \\
1.01(21) \\
0.68(14) \\
1.16(24) \\
1.01(21) \\
0.77(16) \\
1.35(28) \\
0.87(18) \\
1.06(22) \\
1.40(29) \\
1.35(28) \\
0.58(12) \\
0.72(15) \\
1.69(35) \\
1.26(26) \\
1.11(23) \\
1.16(24) \\
0.87(18) \\
1.69(35) \\
0.58(12) \\
0.77(16) \\
0.92(19) \\
1.01(21) \\
1.45(30) \\
1.26(26) \\
1.35(28) \\
1.59(33) \\
0.72(15) \\
0.87(18) \\
1.11(23) \\
0.77(16) \\
0.82(17) \\
1.30(27) \\
1.45(30) \\
1.50(31) \\
1.88(39) \\
1.98(41)\end{array}$ & $\begin{array}{l}24 \cdot 1 \\
27 \cdot 6 \\
28 \cdot 2 \\
27 \cdot 3 \\
30 \cdot 3 \\
43 \cdot 7 \\
21 \cdot 7 \\
24 \cdot 7 \\
14 \cdot 7 \\
24 \cdot 5 \\
16 \cdot 3 \\
24 \cdot 2 \\
21 \cdot 3 \\
29 \cdot 4 \\
38 \cdot 6 \\
23 \cdot 4 \\
34 \cdot 6 \\
31 \cdot 5 \\
34 \cdot 8 \\
37 \cdot 5 \\
47 \cdot 0 \\
24 \cdot 9 \\
29 \cdot 7 \\
33 \cdot 6 \\
28 \cdot 4 \\
39 \cdot 0 \\
45 \cdot 4 \\
22 \cdot 7 \\
24 \cdot 1 \\
30 \cdot 8 \\
29 \cdot 4 \\
34 \cdot 8 \\
31 \cdot 7 \\
43 \cdot 7 \\
= \\
= \\
= \\
= \\
-\end{array}$ \\
\hline $\begin{array}{l}\text { No. } \\
\text { Mean } \\
\text { SD }\end{array}$ & $\begin{array}{l}40 \\
39.8 \\
10.8\end{array}$ & 40 & 40 & $\begin{array}{r}40 \\
11 \\
8\end{array}$ & $\begin{array}{r}38 \\
664 \\
153\end{array}$ & 40 & $\begin{array}{c}40 \\
1 \cdot 10(22 \cdot 8) \\
0 \cdot 37(7 \cdot 6)\end{array}$ & $\begin{array}{r}34 \\
30 \cdot 1 \\
7 \cdot 9\end{array}$ \\
\hline
\end{tabular}

KEY

\begin{tabular}{c|c|cc} 
Allotted no. & $\begin{array}{c}\text { Smoking habits } \\
\text { (daily consumption: } \\
\text { cigarette equivalent) }\end{array}$ & $\begin{array}{c}\text { Drinking habits } \\
\text { (weekly consumption: litres/pints of } \\
\text { beer or eq aivalent in spirits) }\end{array}$ \\
\hline & & (litres) & (pints) \\
\cline { 2 - 3 } 0 & nil & nil & nil \\
1 & up to 5 & up to $1 \cdot 1$ & up to 2 \\
3 & 5 to 14 & $1 \cdot 7-5 \cdot 7$ & 3 to 10 \\
4 & 15 to 24 & $6 \cdot 3-17 \cdot 1$ & 11 to 30 \\
& 25 or more & over $17 \cdot 1$ & over 30
\end{tabular}




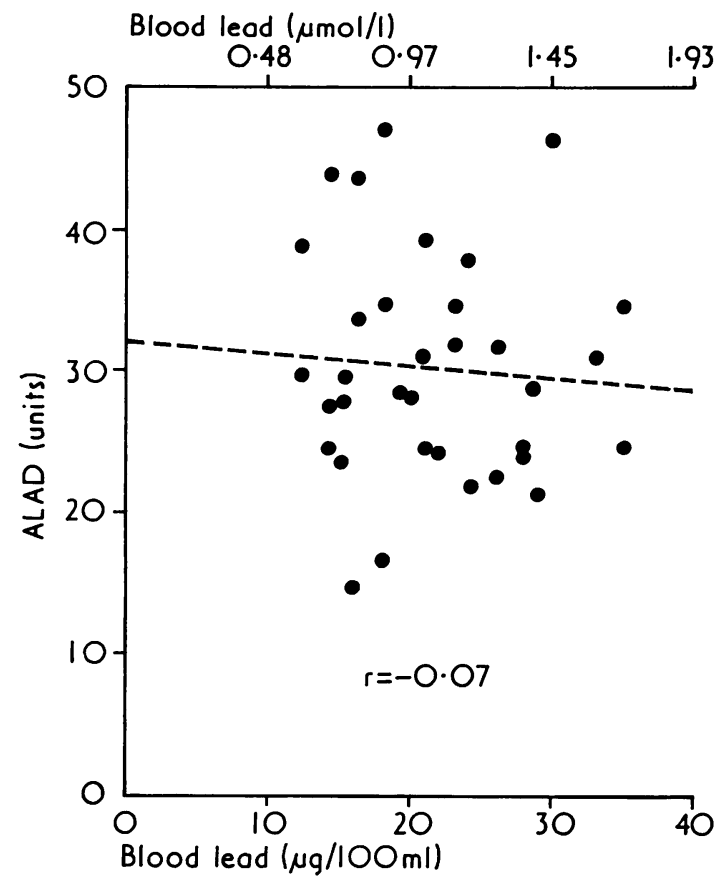

FIGURE Relationship of red-cell ALAD activity with blood lead in 34 taxi drivers.

the water main to their homes was of lead or copper. However, a higher mean blood lead level was found in those whose homes had lead plumbing than in those with copper plumbing (see Table 3 ). The statistical significance of this finding ( $t$ test $\mathrm{P}<0.01)$ must be tempered by the small number in the group with lead plumbing, but the finding is consistent with that of other workers (Beattie et al., 1972; Addis and Moore, 1974). Three of the group with domestic lead plumbing had addresses in the north east quadrant of the city, one in the north west and another in the south west quadrant. If these five individuals are excluded, the geographical comparison narrows the difference between the mean blood leads of those living in the north east quadrant and the other quadrants. The mean blood lead figures then become:

North east $1.16 \mu \mathrm{mol} / 1(24.0 \mu \mathrm{g} / 100 \mathrm{ml})$

North west $0.97 \mu \mathrm{mol} / \mathrm{l}(20.1 \mu \mathrm{g} / 100 \mathrm{ml})$

South west $1.01 \mu \mathrm{mol} / 1(21.0 \mu \mathrm{g} / 100 \mathrm{ml})$

South east $1.04 \mu \mathrm{mol} / \mathrm{l}(21.6 \mu \mathrm{g} / 100 \mathrm{ml})$

The results of levels of lead in blood from two other groups of Manchester residents were available from the same laboratory. The first groupconsisted of 27 adult first aid students without occupational lead exposure. Their mean blood lead was $1.05 \mu \mathrm{mol} / \mathrm{l}$, SD $0.50(21.7 \mu \mathrm{g} / 100 \mathrm{ml}$, SD 10.35). There were 13 men, mean blood lead $1.18 \mu \mathrm{mol} / 1$, SD 0.50 $(24.38 \mu \mathrm{g} / 100 \mathrm{ml}, \mathrm{SD} 10.35)$ and 14 women, mean blood lead $0.93 \mu \mathrm{mol} / 1$, SD $0.45(19.21 \mu \mathrm{g} / 100 \mathrm{ml}$, SD 9.28). The second was a group of 25 male factory workers without significant occupational lead exposure. The mean blood lead of this second group was $1 \cdot 16 \mu \mathrm{mol} / \mathrm{l}$, SD $0 \cdot 26(24.04 \mu \mathrm{g} / 100 \mathrm{ml}$, SD 5.3). It will be seen that the results for the taxi drivers do not differ significantly from those obtained for the men in these other groups.

There was no indication that the ALAD levels of our group of taxi drivers differed significantly from those of control individuals whose places of work

TABLE 2

LOCATION OF Home AdDRESSES

\begin{tabular}{|c|c|c|c|c|}
\hline \multirow{2}{*}{ Quadrant } & \multirow{2}{*}{ No. } & \multicolumn{3}{|c|}{ Blood lead $\mu \mathrm{mol} / \mathrm{l}(\mu \mathrm{g} / 100 \mathrm{ml})$} \\
\hline & & Mean & $S D$ & $S E$ mean \\
\hline $\begin{array}{l}\text { North west } \\
\text { North east } \\
\text { South west } \\
\text { South east }\end{array}$ & $\begin{array}{r}11 \\
13 \\
10 \\
5\end{array}$ & $\begin{array}{l}1.04(21.45) \\
1.26(26.00) \\
1.04(21.60) \\
1.04(21.60)\end{array}$ & $\begin{array}{l}0.33(6.79) \\
0.34(7.06) \\
0.36(7.40) \\
0.53(10.92)\end{array}$ & $\begin{array}{l}0.10(2.05) \\
0.09(1.96) \\
0 \cdot 11(2.34) \\
0.24(4.88)\end{array}$ \\
\hline
\end{tabular}

TABLE 3

Domestic Plumbing

\begin{tabular}{|c|c|c|c|c|c|}
\hline \multirow{2}{*}{ Plumbing material } & \multirow{2}{*}{ No. } & \multicolumn{4}{|c|}{ Blood lead $\mu \mathrm{mol} / \mathrm{l}(\mu \mathrm{g} / 100 \mathrm{ml})$} \\
\hline & & Range & Mean & $S D$ & $S E$ mean \\
\hline $\begin{array}{l}\text { Lead } \\
\text { Copper }\end{array}$ & $\begin{array}{r}5 \\
29\end{array}$ & $\begin{array}{c}1 \cdot 26-1 \cdot 88 \\
(26-39) \\
0 \cdot 58-1 \cdot 98 \\
(12-41)\end{array}$ & $\begin{array}{c}1 \cdot 52 \\
(31 \cdot 4) \\
1 \cdot 00 \\
(20 \cdot 8)\end{array}$ & $\begin{array}{c}0.27 \\
(5 \cdot 50) \\
0 \cdot 33 \\
(6.91)\end{array}$ & $\begin{array}{c}0.12 \\
(2 \cdot 46) \\
0.06 \\
(1 \cdot 28)\end{array}$ \\
\hline
\end{tabular}


were away from city streets. The mean ALAD level from a group of 15 Manchester hospital workers was 28 units (SD 5.5) which is very close to that of the taxi drivers.

In our group of taxi drivers the negative corre lation between blood lead levels and ALAD activity was not statistically significant. However, if we exclure those series in which there has been relatively heivy lead exposure, or where the ALAD activity has fallen in association with a recent rise in blood lead, as occurs in new lead workers, not all investigators have found correlations at all blood lead levels (Calandra, 1971; Kennedy, Dressler, and Keplinger, 1972). Kennedy et al. (1972), in their survey of 300 randomly selected individuals and 30 lead workers, found an inverse relationship between ALAD and blood lead at blood lead levels above $1.21 \mu \mathrm{mol} / 1(25 \mu \mathrm{g}$ per $100 \mathrm{ml})$. There were 10 individuals in our series with blood lead levels above $1 \cdot 21 \mu \mathrm{mol} / 1(25 \mu \mathrm{g}$ per $100 \mathrm{ml})$, but there was not an inverse correlation between their blood lead levels and erythrocyte ALAD activity. However, low levels of ALAD activity were found in six occupationally lead-exposed individuals with blood lead levels between 2.51 and $8.21 \mu \mathrm{mol} / \mathrm{l}$ (52 and $170 \mu \mathrm{g} / 100 \mathrm{ml}$ ), who attended hospital during our investigation. Their ALAD levels ranged between 6.3 and 20.6 units, with a mean of 13.5 units (Table 4).

The lack of correlation between the reported drinking habits of the drivers and their erythrocyte ALAD levels is not necessarily inconsistent with the finding of Moore et al. (1971) in respect of recent alcohol consumption. In their investigation the depression of erythrocyte ALAD levels closely matched the increase in blood ethanol levels after ingestion, and rose to normal levels within a few hours as the blood ethanol fell. The reported drinking habits of our drivers was a customary weekly consumption, classified on an arbitrary fivepoint scale. Most of those who drank confined their drinking to weekends or off-duty evenings. Our blood samples were taken during the day while the men were at work, and our results confirm the likelihood that professional drivers would not ordinarily hazard their passengers or their licences by driving with significant levels of alcohol in their blood. The nearest indication that relatively recent alcohol consumption might depress erythrocyte ALAD levels was that the lowest ALAD level recorded in this series (14.7 units) was in a non-smoking man who said he had consumed a lot of whisky during a special celebration two nights before the blood sample was taken and had drunk $2 \cdot 8$ litres ( 5 pints) of beer on the previous night. His blood lead level was only $0.77 \mu \mathrm{mol} / 1(16 \mu \mathrm{g} / 100 \mathrm{ml})$.

From our findings it seems unlikely that, by virtue of their occupation, these urban Manchester taxi drivers were absorbing significantly more lead than their fellow-citizens. This conclusion supports that of Jones et al. (1972) concerning the relative unimportance of the contribution of inhaled lead while driving in city streets to the blood lead levels of their group of London taxi drivers. However, in neither the Manchester taxi drivers nor our control groups did we find mean blood lead levels of the order quoted for the London drivers, the mean level of the London drivers being significantly higher $(P<0.001)$ than that of the Manchester drivers. Factors associated with water supply are unlikely to account for the difference as water supplied to London is harder than that supplied to Manchester. Assuming there were no other environmental differences, the disparity might be explained if the direct atomic absorption technique of lead assay used in the London investigation did not incorporate a correction for non-resonant absorption (King, 1974; Delves, 1974).

We thank Mr and Mrs Marks of the Manchester and Salford Taxi Owners' Association and the volunteers for their co-operation; Mr P. Whatmough, Chief Chemist and Bacteriologist to the Manchester Supply Unit of the North West Water Authority, and his staff for information concerning water supplies, and Mr E. Moss for statistical advice.

\section{References}

Addis, G. and Moore, M. R. (1974). Lead levels in the water of suburban Glasgow. Nature (London), 252, 120-121.

TABLE 4

Blood Lead and Alad levels in Hospital Patients with Occupational Lead Exposure

\begin{tabular}{c|c|c} 
Case no. & $\begin{array}{c}\text { Blood lead } \mu \mathrm{mol} / \mathrm{l} \\
(\mu \mathrm{g} / \mathrm{I00} \mathrm{ml})\end{array}$ & ALAD (units) \\
\hline 1 & $2 \cdot 51(52)$ & $11 \cdot 7$ \\
2 & $3 \cdot 48(72)$ & $17 \cdot 8$ \\
3 & $3 \cdot 48(72)$ & $13 \cdot 5$ \\
4 & $3 \cdot 86(80)$ & $20 \cdot 6$ \\
5 & $5 \cdot 89(122)$ & $11 \cdot 1$ \\
6 & $8 \cdot 21(170)$ & $6 \cdot 2$ \\
\hline
\end{tabular}


Arroyo, M. and Soldevilla, L. (1970). Levels of lead in the blood of the general population. Medicina $y$ seguridad del trabajo, 18, 15-20.

Beattie, A. D., Moore, M. R., Devenay, W. T., Miller, A. R., and Goldberg, A. (1972). Environmental lead pollution in an urban soft-water area. British Medical Journal, 1, 491-493.

Calandra, J. C. (1971). Statement before the Senate Transportation Committee of the State of California, 11-12.

Delves, H. T. (1974). The determination of lead and cadmium in blood by atomic absorption spectroscopy, paper 143. International Symposium on Recent Advances in the Assessment of the Health Effects of Environmental Pollution, Paris.

Gibson, K. D., Neuberger, A., and Scott, J. H. (1955). The purification and properties of delta-aminolaevulinic acid dehydrase. Biochemical Journal, 61, 618-629.

Goldwater, L. J. and Hoover, A. W. (1967). An international study of 'normal' levels of lead in blood and urine. Archives of Environmental Health, 15, 60-63.

Hernberg, S. and Nikkanen, J. (1970). Enzyme inhibition by lead under normal urban conditions. Lancet, 1, 63-64.

-, , Mellin, G., and Lilius, H. (1970). Deltaaminolaevulinic acid dehydrase as a measure of lead exposure. Archives of Environmental Health, 21, 140-145.

, Tola, S., Nikkanen, J., and Valkonen, S. (1972). Erythrocyte delta-aminolevulinic acid dehydratase in new lead exposure. Archives of Environmental Health, 25, 109-113.

Hoschek, R. and Schittke, H. J. (1973). Vergleichsbestimmungen für Blei im Blut Sowie für Blei und Kadmium im Urin, Forschungsbericht $\mathrm{Nr}$ 101, Bundesanstalt Arbeitsschutz und Unfällforschung, Dortmund. (Hug \& Co. 194 Wilhelmshaven, Rathausplatz 4-6), 79-83.

Jones, R. D., Commins, B. T., and Cernik, A. A. (1972). Blood lead and carboxyhaemoglobin levels in London taxi drivers. Lancet, 2, 302-303.
Kennedy, G. L., Dressler, I. A., and Keplinger, M. L. (1972). Relationship of delta-aminolevulinic acid dehydrase (ALAD) and blood lead levels in normal and lead exposed populations (paper given at American Industrial Hygiene Association Conference, San Francisco, 14-19 May 1972). American Industrial Hygiene Association Journal, 33, No. 2 (Abstract no. 43 p. 19).

King, E. (1974). 'Normal' blood lead levels. British Medical Journal, 1, 116.

Lehnert, G. (1967). Lead-new data and technical measures concerned with occupational health. Arbeitsschutz und Arbeitsmedizin, Supplement No. 2, Frankfurt, 91.

Ludwig, J. H., Diggs, D. R., Hesselberg, H. E., and Maga, J. A. (1965). Survey of lead in the atmosphere of three urban communities. American Industrial Hygiene Association Journal, 26, 270-284.

Mann, P., Senchea, A., and Roventa, A. (1969). Investigations of the normal content of lead in blood. Igiena (Bucharest), 18, 135-142.

Moore, M. R., Beattie, A. D., Thompson, G. G., and Goldberg, A. (1971). Depression of delta-aminolaevulinic acid dehydrase activity by alcohol in man and rat. Clinical Science, 40, 81-88.

Thomas, H. V., Milmore, B. K., Heidbreder, G. A., and Kogan, B. A. (1967). Blood lead of persons living near freeways. Archives of Environmental Health, 15, 695 . 702.

Weissberg, J. B., Lipschutz, F., and Oski, F. A. (1971). Delta-aminolevulinic acid dehydratase activity in circulating blood cells. New England Journal of Medicine, 284, 565-569.

Zurlo, N., Griffini, A. M., and Vigliani, E. C. (1970). The content of lead in blood and urine of adults, living in Milan, not occupationally exposed to lead. American Industrial Hygiene Association Journal, 31, 92-95.

Received for publication 11 August 1975

Accepted for publication 5 December 1975 